\title{
SYSTEMATIC REVIEW ON ANTEGRADE INTRAMEDULLARY PINNING VERSUS RETROGRADE INTRAMEDULLARY PINNING IN BOXER'S FRACTURE (A SYSTEMATIC REVIEW)
}

\author{
Mohammed Mostafa Al Mahy*, Ramy Ahmed Diab*, and \\ Mohammed Khairy Amin**
}

*Orthopedic Surgery Department,
Faculty of Medicine, Ain Shams
University
**Resident, Fayoum General
Hospital
Corresponding author
Mohammed Khairy Amin
Mobile: (+2) 01010183789
E.mail:
egydoc35@gmail.com
Received: 15/4/2021
Accepted: 13/5/2021

Online ISSN: 2735-3540

\begin{abstract}
:
Background: The literature is limited concerning the issues of fracture in the fifth metacarpal bone with no robust evidence for the best treatment practice for metacarpal neck fractures. The purpose of this review was to investigate whether the ante grade intramedullary $k$ wires compared to retrograde intramedullary $k$-wires results in good clinical and radiological outcomes for displaced metacarpal neck fractures.
\end{abstract}

Aim of the Work: To perform a comparative systematic review to determine whether there is a significant difference in the clinical outcome and complication between ante grade and retrograde intramedullary nailing of fracture neck in Boxer's fracture.

Patients and Methods: We searched in four different databases for the relevant articles including PubMed, SCOPUS, and Cochrane Central Register of Controlled Trials (CENTRAL) till October 2020. We included randomized controlled trials (RCTs), comparative studies, prospective cohort, or retrospective charts studies that compared ante grade intramedullary $k$-wires to retrograde intramedullary $k$-wires in displaced fifth metacarpal bone. Our primary outcome was ROM, Grip strength, DASH and VAS. Our secondary outcomes were complication rates and other outcomes that were consistently reported across studies.

Results: From a total 224 screened citations, three studies met our inclusion criteria. All three studies reported that ante grade intramedullary pinning was superior to retrograde intramedullary pinning in term of ROM, VAS, grip strength, DASH scores and early return to work. Also ante grade intramedullary pinning had better satisfaction in terms of comfort and tenderness. But some theses clinical parameters become statistically non-significant between both methods with long duration of follow up. Both techniques had similar radiographic outcomes and improvement in preoperative angulation and shortening. We highlighted the need for a standardization of the outcomes across studies and the need for larger studies the compare between both techniques.

Conclusion: Ante grade intramedullary $k$-wires is superior to retrograde intramedullary $k$-wires regarding early restoration of hand movement in the short term follow up.

Keywords: Ante grade Intramedullary Pinning, Retrograde Intramedullary Pinning, Boxer's Fracture. 


\section{INTRODUCTION:}

Boxer's fracture: Metacarpal neck fractures account for $40 \%$ of all hand fractures. A fracture of the neck of the fifth metacarpal, or Boxer's fracture ${ }^{(\mathbf{1})}$, named for the classic mechanism of injury in which direct trauma is applied to a clenched fist, is the most common, representing $10 \%$ of all hand fractures ${ }^{(2)}$.

Etiology: The most common mechanism of injury for Boxer's fracture is punching, e.g., the axial pressure applied to the metacarpal bone when the fist is in a clenched position. Direct trauma to the dorsum of the hand may also cause a fracture of the fifth metacarpal neck ${ }^{(\mathbf{3})}$.

Pathophysiology: Direct trauma to a clenched fist transfers energy to the metacarpal bone axially, causing fractures most commonly at the neck, and typically resulting in apex dorsal angulation due in part to the forces exerted by the pull of the interosseous muscles. The interosseous muscles, responsible for adduction and abduction of the fingers, originate from the metacarpal shafts and insert onto proximal phalanges. The collateral ligaments also join the metacarpal bones to the proximal phalanges and must be taken into consideration during splinting to minimize the risk of loss of motion due to shortening of the ligaments. The ligaments are taut in flexion, and more slack in extension ${ }^{(4)}$.

History and physical examination: Patients with Boxer's fractures present with complaints of dorsal hand pain, edema, and possible deformity in the setting of one of the mechanisms typically associated with this injury involving direct trauma to the hand. Complete physical exam of a potential Boxer's fracture should include an examination of the entire hand, comparison to the contralateral (presumably un injured) hand, with special attention to the following:
Neurovascular: should test for sensation, motor function, and blood flow distal to the injury $^{(5)}$.

Angulation: Boxer's fractures are typically associated with apex dorsal angulation, thereby resulting in depression of the MCP joint and loss of the normal knuckle contour ${ }^{(5)}$.

Skin: Closely inspect the skin for any breaks, malrotation: can be detected by examining the hand with the MCPs flexed, and PIPs and DIPs extended. The finger nails should point towards the scaphoid tubercle $^{(\mathbf{5})}$.

Radiological Evaluation: Plain radiographs are the standard of care to diagnose Boxer's fractures and determine a degree of angulation.

Poster anterior, lateral, and oblique views should be obtained. The lateral view should be used to measure the degree of angulation of the shaft of the metacarpal as compared to the mid-point of the fracture fragment. Normal angulation of the metacarpal head to the neck is 15 degrees ${ }^{(6)}$.

CT is generally not used for the diagnosis of metacarpal fractures; however occult fractures may be detected via $\mathrm{CT}^{(7)}$.

Conservative management: Closed reduction is required for a Boxer's fracture with significant angulation. The fifth metacarpal can tolerate angulation of up to 30 degrees. Closed reduction and immobilization is indicated for fractures with angulation greater than 30 degrees. Fractures with pseudo-clawing should also undergo closed reduction. Analgesia options for the procedure include a hematoma block or an ulnar nerve block ${ }^{(\mathbf{8})}$.

Closed reduction of a Boxer's frby using the "90-90 method." The MCP, DIP, and PIP joints should all be flexed to 90 degrees. The clinician should then apply volar pressure over the dorsal aspect of the fracture site while applying pressure axially 
to the flexed PIP joint. This axial pressure to the PIP applies dorsal force to the distal fracture fragment. The injury should be immobilized with an ulnar gutter splint, and post- reduction films should be taken to assess for adequate reduction ${ }^{(9)}$.

Follow up: Boxer's fractures should be sent for repeat radiographs within one week to assess alignment. Radiographs should be obtained every two weeks following, until clinical and radiological healing are present, typically between four to six weeks ${ }^{(10)}$.

Surgical treatment: Several surgical techniques have been used to treat displaced fifth metacarpal neck fractures. The most commonly used techniques are the ante grade intramedullary pinning technique and the retrograde percutaneous intramedullary pinning technique. Both techniques provide satisfactory outcomes with minimal complications $^{(\mathbf{1 1})}$.

Indications of surgery: Open and severely comminuted fractures associated with neurovascular injury ${ }^{(\mathbf{1 2})}$.

Angular displacement of the fifth metacarpal neck angle by $30^{\circ}$ on the injured side compared with that on the contralateral, uninjured side in a $30^{\circ}$ pronated oblique radiograph, shortening of $3 \mathrm{~mm}$ compared with the contralateral, uninjured metacarpal measured in a posteroanterior and Radiograph. Any degree of rotational deformity that is evident by physical examination ${ }^{(\mathbf{1 3})}$.

\section{AIM OF THE WORK:}

To perform a comparative systematic review to determine whether there is a significant difference in the clinical outcome and complication between ante grade and retrograde intramedullary nailing of fracture neck in Boxer's fracture.

\section{PATIENTS AND METHODS:}

We performed this systematic review and meta-analysis in accordance to the recommendations of the Preferred Reporting Items for Systematic Reviews and MetaAnalyses (PRISMA) statement and Metaanalysis Of Observational Studies in Epidemiology (MOOSE) statement. PRISMA and MOOSE are reporting checklists for Authors, Editors, and Reviewers of Meta-analyses of interventional and observational studies. According to International committee of medical journal association (ICJME), reviewers must report their findings according to each of the items listed in those checklists ${ }^{(\mathbf{1 4})}$.

The present review included studies that fulfilled the following criteria: Studies that included adult patients with Boxer's fracture, studies that compared ante grade and retrograde $\mathrm{K}$-wires fixation techniques for Boxer's fracture, studies that reported any of the following outcomes: ROM $\left({ }^{\circ}\right)$, Grip strength (\% of un injured hand), Palmar displacement at time of injury $\left({ }^{\circ}\right)$, Palmar displacement at time of follow-up $\left({ }^{\circ}\right)$, Shortening at time of follow-up (mm), DASH score (points), VAS (points), and/or Complications, studies that were randomized controlled trials (RCTs), comparative studies, prospective cohort, or retrospective studies.

We excluded non-English studies, theses and conference abstracts.

Search Strategy and Screening: An electronic search was conducted from 2000s till October 2020 in the following bibliographic databases: Medline via PubMed, SCOPUS, Cochrane Central Register of Controlled Trials (CENTRAL), and Web of Science to identify relevant articles. We used different combinations of the following queries: 'metacarpal fractures" OR "boxer's fracture" OR "fifth metacarpal fracture" OR “little finger fracture'.

Screening: Retrieved citations were imported into End Note X7 for duplicates removal. Subsequently, unique citations 
were imported into an Excel sheet and screened by two independent reviewers; the screening was conducted in two steps: title and abstract screening, followed by a fulltexts screening of potentially eligible records.

Data Extraction: Data entry and processing were carried out using a standardized Excel sheet and reviewers extracted the data from the included studies. The extracted data included the following domains: Characteristics of the included studies; Baseline data of studied populations; and Study outcomes. All reviewers' independently extracted data from the included articles and any discrepancies were solved by discussion.

Risk of Bias Assessment: The quality of the retrieved RCTs was assessed according to the Cochrane Handbook for
Systematic Reviews of Interventions 5.1.0 (updated March 2011) using the quality assessment table provided in the same book (part 2, Chapter 8.5). The Cochrane risk of bias assessment tool includes the following domains: sequence generation (selection bias), allocation sequence concealment (selection bias), blinding of participants and personnel (performance bias), blinding of outcome assessment (detection bias), incomplete outcome data (attrition bias), selective outcome reporting (reporting bias) and other potential sources of bias. The authors' judgment is categorized as 'Low risk', 'High risk' or 'Unclear risk' of bias.

Dealing with Missing Data: Missing standard deviation (SD) of mean change from baseline was calculated from standard error or 95\% confidence interval (CI) according to Altman ${ }^{(15)}$.

\section{RESULTS}

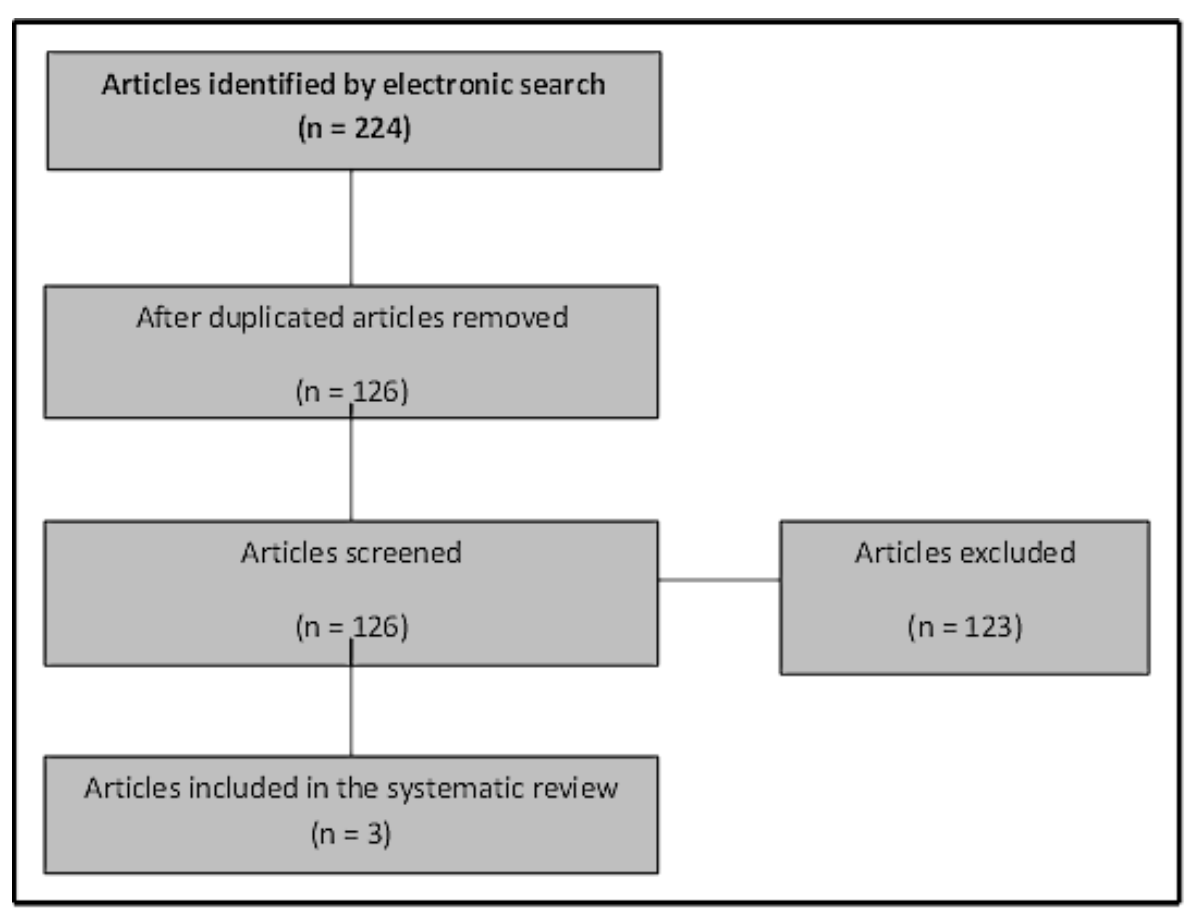

Diagram (1): PRISMA Flow Diagram 
Table (1): Baseline data of the included studies:

\begin{tabular}{|c|c|c|c|c|c|c|c|c|c|c|c|}
\hline Author & Groups & $\begin{array}{c}\text { Number } \\
\text { of } \\
\text { patients }\end{array}$ & $\begin{array}{c}\text { Age } \\
\text { median } \\
\text { (range) } \\
\text { (years) }\end{array}$ & Male/female & $\begin{array}{l}\text { Dominant } \\
\text { hand } \\
\text { affected }\end{array}$ & \begin{tabular}{|c|} 
Apex \\
dorsal \\
angulation \\
(degrees) \\
median \\
(range) \\
\end{tabular} & $\begin{array}{c}\text { Shortening } \\
\text { median } \\
\text { (range) } \\
(\mathrm{mm})\end{array}$ & $\begin{array}{c}\text { Operation } \\
\text { time } \\
\text { (min) }\end{array}$ & $\left|\begin{array}{c}\text { Immobilization } \\
\text { time (weeks) }\end{array}\right|$ & $\begin{array}{c}\text { Pin } \\
\text { removal } \\
\text { (weeks) }\end{array}$ & $\left|\begin{array}{c}\text { Follow- } \\
\text { up } \\
\text { (months) }\end{array}\right|$ \\
\hline \multirow[t]{2}{*}{ Hopfne et al, } & $\begin{array}{c}\text { Antegrade } \\
\text { intramedullary } \\
\text { pinning }\end{array}$ & 15 & $\begin{array}{c}26 \\
(15-46)\end{array}$ & $15 / 0$ & 11 & NA & NA & $\begin{array}{c}45 \\
(15-60)\end{array}$ & $4(3-5)$ & $6(4-6)$ & $\begin{array}{c}17 \\
(6-34)\end{array}$ \\
\hline & $\begin{array}{c}\text { Retrograde } \\
\text { intramedullary } \\
\text { pinning }\end{array}$ & 15 & $\begin{array}{c}25 \\
(16-52)\end{array}$ & $14 / 1$ & 14 & NA & NA & $\begin{array}{c}35 \\
(20-90)\end{array}$ & $4(3-5)$ & $5(4-6)$ & $\begin{array}{c}18 \\
(12-41)\end{array}$ \\
\hline \multirow[t]{2}{*}{ Kim et al, } & $\begin{array}{c}\text { Antegrade } \\
\text { intramedullary } \\
\text { pinning } \\
\end{array}$ & 23 & $\begin{array}{c}31 \\
(18-53)\end{array}$ & $23 / 0$ & $20 / 3$ & $\begin{array}{c}44 \\
(31-68)\end{array}$ & $4(2-6)$ & NA & NA & 5 & $(3-6)$ \\
\hline & $\begin{array}{l}\text { Percutaneous } \\
\text { retrograde } \\
\text { intramedullary } \\
\text { pinning }\end{array}$ & 23 & $\begin{array}{c}32 \\
(19-54)\end{array}$ & $23 / 0$ & $21 / 2$ & $\begin{array}{c}44 \\
(31-66)\end{array}$ & $4(2-6)$ & NA & NA & 8 & $(3-6)$ \\
\hline \multirow[t]{2}{*}{ Moon et al. } & $\begin{array}{c}\text { Antegrade } \\
\text { intramedullary } \\
\text { pinning }\end{array}$ & 14 & $\begin{array}{c}28 \\
(15-49)\end{array}$ & 14 & 14 & $\begin{array}{c}48 \\
(20-74)\end{array}$ & $8.1(0-19)$ & 48 & NA & NA & 3 \\
\hline & $\begin{array}{l}\text { Percutaneous } \\
\text { retrograde } \\
\text { intramedullary } \\
\text { pinning }\end{array}$ & 17 & $\begin{array}{c}34 \\
(9-71)\end{array}$ & $14 / 3$ & 17 & $\begin{array}{c}41 \\
(0-82)\end{array}$ & $7.7(0-17)$ & 34 & NA & NA & 3.5 \\
\hline
\end{tabular}

Table (2): Characteristics of the included studies

\begin{tabular}{|c|c|c|c|c|c|c|c|c|c|}
\hline Author & Year & Country & $\begin{array}{l}\text { Study } \\
\text { period }\end{array}$ & $\begin{array}{c}\text { Study } \\
\text { design }\end{array}$ & $\begin{array}{l}\text { Level of } \\
\text { evidence }\end{array}$ & Population & Groups & \begin{tabular}{|c|} 
Sample \\
size
\end{tabular} & Conclusion \\
\hline \multirow[t]{2}{*}{ Hopfne et al, } & \multirow[t]{2}{*}{2007} & \multirow[t]{2}{*}{ Germany } & $\begin{array}{c}1998 \\
\text { and } \\
1999\end{array}$ & \multirow[t]{2}{*}{$\begin{array}{l}\text { prospective } \\
\text { Case series }\end{array}$} & \multirow[t]{2}{*}{ Level II } & \multirow{2}{*}{\begin{tabular}{|} 
patients with \\
displaced neck \\
fractures of the \\
fifth metacarpal
\end{tabular}} & $\begin{array}{c}\text { antegrade } \\
\text { intramedullary } \\
\text { pinning }\end{array}$ & 15 & \multirow{2}{*}{$\begin{array}{l}\text { AIMN is superior to retrograde } \\
\text { retrograde intramedullary pinning } \\
\text { and thus should be preferentially } \\
\text { considered for displaced neck } \\
\text { fractures of the fifth metacarpal. }\end{array}$} \\
\hline & & & $\begin{array}{c}1999 \\
\text { and } \\
2001\end{array}$ & & & & $\begin{array}{c}\text { Retrograde } \\
\text { intramedullary } \\
\text { pinning }\end{array}$ & 15 & \\
\hline \multirow[t]{2}{*}{ Kim et al, } & \multirow[t]{2}{*}{2014} & \multirow[t]{2}{*}{$\begin{array}{l}\text { South } \\
\text { Korea }\end{array}$} & \multirow{2}{*}{$\begin{array}{c}\text { January } \\
2011 \text { to } \\
\text { January } \\
2013\end{array}$} & \multirow[t]{2}{*}{$\begin{array}{l}\text { Randomized } \\
\text { prospective } \\
\text { study }\end{array}$} & \multirow[t]{2}{*}{ Level 1} & \multirow{2}{*}{$\begin{array}{c}\text { patients with } \\
\text { displaced fifth } \\
\text { metacarpal } \\
\text { neck fractures } \\
\text { with an apex } \\
\text { dorsal } \\
\text { angulation } \\
\text { greater than } 30^{\circ}\end{array}$} & $\begin{array}{c}\text { antegrade } \\
\text { intramedullary } \\
\text { pinning } \\
\end{array}$ & 23 & \multirow[b]{2}{*}{$\begin{array}{l}\text { - Antegrade intramedullary } \\
\text { pinning has some clinical advantages } \\
\text { during the early recovery period over } \\
\text { percutaneous retrograde } \\
\text { intramedullary pinning, but the } \\
\text { advantages are not evident at } 6 \\
\text { months postoperatively. } \\
\text { - no differences in radiographic } \\
\text { outcomes between antegrade and } \\
\text { retrograde techniques. } \\
\text { - For patients who require an } \\
\text { early return of hand function, such as } \\
\text { athletes, antegrade intramedullary } \\
\text { pinning can be recommended. } \\
\text { - Otherwise, treatment could be } \\
\text { decided according to the surgeon's } \\
\text { preference and patient status. }\end{array}$} \\
\hline & & & & & & & $\begin{array}{l}\text { percutaneous } \\
\text { retrograde } \\
\text { intramedullary } \\
\text { pinning }\end{array}$ & 23 & \\
\hline \multirow[t]{2}{*}{ Moon et al., } & \multirow[t]{2}{*}{2014} & \multirow[t]{2}{*}{$\begin{array}{l}\text { South } \\
\text { Korea }\end{array}$} & \multirow[t]{2}{*}{$\begin{array}{l}2011- \\
2013\end{array}$} & \multirow[t]{2}{*}{ Retrospective } & \multirow[t]{2}{*}{ Level IV } & \multirow[t]{2}{*}{$\begin{array}{c}\text { Fractures neck } \\
\text { of fifth } \mathrm{MCB}\end{array}$} & $\begin{array}{c}\text { Antegrade } \\
\text { Intramedullary } \\
\text { Nailing }\end{array}$ & 14 & \multirow{2}{*}{$\begin{array}{l}\text { Antegrade Intramedullary nailing } \\
\text { fixation is advisable for fractures in } \\
\text { the neck of fifth the metacarpal bone. } \\
\text { It provides early recovery of the } \\
\text { range of motion, an earlier return to } \\
\text { work, and lower complication rates. }\end{array}$} \\
\hline & & & & & & & $\begin{array}{l}\text { Percutaneous } \\
\text { retrograde } \\
\text { pinning }\end{array}$ & 17 & \\
\hline
\end{tabular}


Table (3): Outcomes of the included studies

\begin{tabular}{|c|c|c|c|c|c|c|c|c|c|c|}
\hline \multirow[t]{2}{*}{ Author } & \multirow[t]{2}{*}{ Groups } & \multirow[t]{2}{*}{$\begin{array}{c}\text { Sample } \\
\text { size }\end{array}$} & $\operatorname{ROM}\left({ }^{\circ}\right)$ & $\begin{array}{c}\text { Grip strength } \\
\text { (\% of } \\
\text { uninjured } \\
\text { hand) }\end{array}$ & \begin{tabular}{|c} 
Palmar \\
displacement \\
at time of \\
injury $\left(^{\circ}\right)$
\end{tabular} & $\begin{array}{c}\text { Palmar } \\
\text { displacement } \\
\text { at time of } \\
\text { follow-up }\left({ }^{\circ}\right)\end{array}$ & $\begin{array}{c}\begin{array}{c}\text { Shortening at } \\
\text { time } \\
\text { of follow-up } \\
(\mathrm{mm})\end{array} \\
\end{array}$ & $\begin{array}{l}\text { DASH } \\
\text { score } \\
\text { (points) }\end{array}$ & $\begin{array}{c}\text { VAS } \\
\text { (points) }\end{array}$ & Steel score \\
\hline & & & $\begin{array}{c}\text { median } \\
\text { (range) }\end{array}$ & $\begin{array}{l}\text { median } \\
\text { (range) }\end{array}$ & $\begin{array}{r}\text { median } \\
\text { (range) }\end{array}$ & $\begin{array}{c}\text { median } \\
\text { (range) }\end{array}$ & $\begin{array}{l}\text { median } \\
\text { (range) }\end{array}$ & $\begin{array}{l}\text { median } \\
\text { (range) }\end{array}$ & $\begin{array}{l}\text { median } \\
\text { (range) }\end{array}$ & $\begin{array}{l}\text { median } \\
\text { (range) }\end{array}$ \\
\hline \multirow[t]{2}{*}{$\begin{array}{c}\text { Hopfne et } \\
\text { al, }\end{array}$} & $\begin{array}{c}\text { Antegrade } \\
\text { intramedullary } \\
\text { splinting }\end{array}$ & 15 & $82(63-90)$ & $\begin{array}{c}100(89: \\
114)\end{array}$ & $45(30: 60)$ & $0(0: 30)$ & $0(0-0)$ & $0.8(0: 25)$ & $0(0: 30)$ & $\begin{array}{c}400 \\
(366: 400)\end{array}$ \\
\hline & $\begin{array}{c}\text { Retrograde } \\
\text { osteosynthesis }\end{array}$ & 15 & $79(54-90)$ & $\begin{array}{l}100(83: \\
117)\end{array}$ & $45(30: 55)$ & $0(0: 30)$ & $0(0-3)$ & $\begin{array}{c}3.3(0: \\
42.5)\end{array}$ & $5(0: 43)$ & $\begin{array}{c}357 \\
(267: 400)\end{array}$ \\
\hline \multirow[t]{2}{*}{ Kim et al } & $\begin{array}{c}\text { Antegrade } \\
\text { intramedullary } \\
\text { pinning }\end{array}$ & 23 & $\begin{array}{l}\text { (3 months) } \\
80(57-90) \\
\\
(6 \text { months) } \\
88(81-90)\end{array}$ & $\begin{array}{c}\text { (3 months) } \\
81(60: 100) \\
\\
(6 \text { months) } \\
93 \text { (78: 104) }\end{array}$ & NA & NA & NA & $\begin{array}{c}3 \\
\text { months }) \\
4.3(0: \\
15.8) \\
(6 \\
\text { months }) \\
3(0: 12.5) \\
\end{array}$ & $\begin{array}{c}3 \\
\text { months }) \\
2(0: 5) \\
\\
(6 \\
\text { months }) \\
1(0: 2) \\
\end{array}$ & $\mathrm{NA}$ \\
\hline & $\begin{array}{l}\text { percutaneous } \\
\text { retrograde } \\
\text { intramedullary } \\
\text { pinning }\end{array}$ & 23 & $\begin{array}{l}69(45-90) \\
87(80-90)\end{array}$ & $\begin{array}{c}\text { 71(49:98) } \\
91(76: 101)\end{array}$ & NA & NA & NA & $\begin{array}{c}10.3(0: \\
28.4) \\
4.3(0- \\
15.8)\end{array}$ & $\begin{array}{l}4(0: 3) \\
1(0: 8)\end{array}$ & NA \\
\hline \multirow[t]{2}{*}{ Moon et al., } & $\begin{array}{l}\text { antegrade } \\
\text { intramedullary } \\
\text { pinning }\end{array}$ & 14 & $82(64-90)$ & NA & NA & NA & NA & $\mathrm{NA}$ & 9 & NA \\
\hline & $\begin{array}{l}\text { percutaneous } \\
\text { retrograde } \\
\text { intramedullary } \\
\text { pinning }\end{array}$ & 17 & 77 (50-90) & NA & NA & NA & NA & NA & 21 & NA \\
\hline
\end{tabular}

\section{DISCUSSION:}

Fracture of the neck of the fifth metacarpal, "the boxer's fracture", is a common injury, frequently seen in the dominant hand of male patients ${ }^{(\mathbf{1 6})}$. The majority of these fractures remain un displaced or minimally displaced with no rotational deformity and such fractures may be treated by non-operative means with a good functional outcome. However, the more displaced fractures with rotational deformity usually require operative intervention to reduce the volar flexion, rotation and shortening of the distal fragment ${ }^{(17)}$.
Many surgical techniques were used in management of displaced fifth metacarpal including antegrade intramedullary K-wire, retrograde intramedullary $\mathrm{K}$-wire, retrograde cross pinning with $\mathrm{K}$-wire, transverse pinning with K-wire, external fixation, intraosseous wiring and plate fixation ${ }^{(\mathbf{1 8 , 1 9})}$.

Retrograde intramedullary K-wire technique was introduced in management of displaced fifth metacarpal fracture with reliable fracture reduction, excellent ROM and DASH scores ${ }^{(\mathbf{2 0})}$.

In the last decade, the ante grade intramedullary $\mathrm{K}$-wire gained popularity among surgeons because it is minimally invasive and relatively simple ${ }^{(21)}$. Also, it could have some advantages over the use of 
plates or other types of pinning in the treatment for the fifth metacarpal neck fractures.

A systematic review and meta-analysis included four studies with a total 163 participants compared the efficacy of ante grade intramedullary $\mathrm{K}$-wire to other surgical techniques. The pooled estimate showed ante grade intramedullary method was superior to other surgical methods regarding, ROM, lesser residual angulation at the site of fracture, fewer complications and better pain scores ${ }^{(22)}$.

In spite of long history and good results of both techniques still no clear evidence about comparative efficacy of both techniques. Hence we conducted the current study to evaluate the efficacy of closed reduction and internal fixation by ante grade intramedullary k-wires compared to retrograde intramedullary k-wires in adults patients with Boxer`s fracture.

After literature search, we identified three studies that met our inclusion criteria. The included studies were different in their study designs and level of evidence, a prospective case series with Level II evidence $^{(\mathbf{2 3})}$, randomized clinical trial with Level 1 evidence ${ }^{(\mathbf{1 1})}$ and retrospective study with Level IV.

All three studies were consistent in reporting that ante grade intramedullary pinning was superior to retrograde intramedullary pinning; Höpfner et al, Kim and D.J Kim studies reported ROM of the metacarpophalangeal joint was greater in ante grade method than retrograde method.

This may be due to scarred adhesions to the extensor hood caused by retrograde percutaneous crossed pinning ${ }^{(23)}$. However, Moon et al reported in the retrograde percutaneous pinning group, the extension deficit disappeared completely at one or two weeks after wire removal with no cases developed permanent extensor problems ${ }^{(24)}$. Therefore, the extension lag may be caused by the tethering effect of wires and extensor irritation is not serious enough to cause permanent problems.

The included studies were not consistent in showing if ante grade intramedullary pinning still would be superior to retrograde pinning regarding these clinical parameters on long term of follow up. Kim and D.J Kim found after six months of follow up ROM, VAS, grip strength, and DASH scores become non-significant different between both methods despite that these outcomes were superior in ante grade at 3 months ${ }^{(11)}$.

Similarly in Moon et al, there was significant difference between both methods regarding early total active motion score at the fifth week of follow up but no statistically significant difference was noted at the 10th operative week in early total active motion score ${ }^{(24)}$. While Höpfner et al followed both groups for a 17 months and reported that ante grade intramedullary pinning was superior to retrograde pinning $^{(23)}$.

Fujitani and his colleagues conducted a prospective study on 30 patients with a displaced metacarpal neck fracture who were treated with intramedullary nails or lowprofile plates. ROM was better in patients with the intramedullary nail than those underwent low-profile plates only at three months and not at six months of follow up $^{(25)}$.

Another randomized clinical trial compared the outcomes intramedullary pinning to transverse pinning in 36 patients with fracture of the neck of the fifth metacarpal. Intramedullary pinning gave better functional outcomes than transverse pinning up to 3 months duration of follow up but the degree of improvement in the two methods become gradually comparable to each other (26).

A retrospective study on 59 patients with fifth metacarpal neck fracture followed the outcomes of ante grade intramedullary 
pinning and percutaneous transverse pinning after 24 months. There was no significant difference between both groups in terms of pain, ROM, or grip strength ${ }^{(27)}$.

In term of the complications, only Höpfner et al reported incidence of complications; retrograde approach had higher complications rates compared to antegrade approach regarding disturbing deformity $(33.3 \%$ vs. $6.6 \%)$, cosmetic impairment ( $33.3 \%$ vs. $0 \%$ ), residual palmar displacement $(46.6 \%$ vs. $6.6 \%)$ and shortening of the fifth metacarpal(46.6\% vs. $0 \%)$.

Findings from previously mentioned studies suggest that ante grade intramedullary pinning could be recommended for cases that need early return of hand function, such as athletes. Still further studies with a larger sample size will be needed to establish criteria for procedure selection. Otherwise, treatment could be decided according to the surgeon's preference and patient status, and based on consideration of the need for an accessory procedure for pin removal after ante grade intramedullary pinning ${ }^{(11)}$. We highlighted the need for a standardization of the outcomes across studies and the need for larger studies the compare between both techniques.

\section{Conclusion:}

Antegrade intramedullary k-wires is superior to retrograde intramedullary k-wires regarding early restoration of hand movement in the short term follow up.

\section{REFERENCES:}

1. De Jonge JJ, Kingma J, Van der Lei B, Klasen HJ. Fractures of the metacarpals. A retrospective analysis of incidence and aetiology and a review of the Englishlanguage literature. Injury 1994; 25(6):3659.
2. Malik ST and Herron N. Rosenberg, Fifth Metacarpal Fractures. StatPearls [Internet], 2020.

3. Nakashian MN, Pointer L, Owens BD, Wolf JM. Incidence of metacarpal fractures in the US population. Hand 2012; 7(4):42630 .

4. Cotterell IH and Richard MJ. Metacarpal and phalangeal fractures in athletes. Clinics in sports medicine 2015: 34(1): 69-98.

5. Low CK, Wong HC, Low YP, Wong HP. A cadaver study of the effects of dorsal angulation and shortening of the metacarpal shaft on the extension and flexion force ratios of the index and little fingers. The Journal of Hand Surgery: British \& European Volume 1995; 20(5):609-13.

6. Lamraski G, Monsaert A, De Maeseneer M, Haentjens P. Reliability and validity of plain radiographs to assess angulation of small finger metacarpal neck fractures: human cadaveric study. Journal of orthopaedic research 2006; 24(1):37-45.

7. Hindman BW, Kulik WJ, Lee G, Avolio RE. Occult fractures of the carpals and metacarpals: demonstration by CT. American journal of roentgenology 1989; 153(3):529-32.

8. Kollitz KM, Hammert WC, Vedder NB, Huang JI. Metacarpal fractures: treatment and complications. Hand 2014; 9(1):16-23.

9. Burkhalter WE. Closed treatment of hand fractures. The Journal of hand surgery 1989; 14(2):390-3.

10. Meals C and Meals R. Hand fractures: a review of current treatment strategies. The Journal of hand surgery 2013; 38(5):102131.

11. Kim JK and Kim DJ. Antegrade intramedullary pinning versus retrograde intramedullary pinning for displaced fifth metacarpal neck fractures. Clinical Orthopaedics and Related Research ${ }^{\circledR} 2015$; 473(5): 1747-1754.

12. Leinberry C, Ukomadu U, Ilyas A. Metacarpal Fractures and Carpometacarpal Fracture-Dislocations.2013, New Delhi, 
India: Jaypee Brothers Medical Publishers Ltd.

13. Mohammed R, Farook MZ, Newman K. Percutaneous elastic intramedullary nailing of metacarpal fractures: surgical technique and clinical results study. Journal of orthopaedic surgery and research 2011; 6(1):1-5.

14. Moher D, Liberati A, Tetzlaff J, Altman DG. Preferred reporting items for systematic reviews and meta-analyses: the PRISMA statement. Int J Surg 2010; 8(5):336-41.

15. Altman DG and Bland JM. Standard deviations and standard errors. Bmj 2005; 331(7521): 903.

16. Gudmundsen $T$ and Borgen L. Fractures of the fifth metacarpal. Acta Radiologica, 2009. 50(3): 296-300.

17. Dunn JC, Kusnezov N, Orr JD, Pallis M, Mitchell JS. The boxer's fracture: splint immobilization is not necessary. Orthopedics 2016; 39(3):188-92.

18. Galanakis I, Aligizakis A, Katonis P, Papadokostakis G, Stergiopoulos K, Hadjipavlou A. Treatment of closed unstable metacarpal fractures using percutaneous transverse fixation with Kirschner wires. Journal of Trauma and Acute Care Surgery 2003; 55(3):509-13.

19. Orbay JL and Touhami A. The treatment of unstable metacarpal and phalangeal shaft fractures with flexible nonlocking and locking intramedullary nails. Hand clinics 2006; 22(3): 279-286.

20. Rhee SH, Lee SK, Lee SL, Kim J, Baek GH, Lee YH. Prospective multicenter trial of modified retrograde percutaneous intramedullary Kirschner wire fixation for displaced metacarpal neck and shaft fractures. Plastic and reconstructive surgery 2012; 129(3):694-703.
21. Sletten IN, Nordsletten L, Husby T, Ødegaard RA, Hellund JC, Kvernmo HD. Isolated, extra-articular neck and shaft fractures of the 4th and 5th metacarpals: a comparison of transverse and bouquet (intra-medullary) pinning in 67 patients. Journal of Hand Surgery (European Volume) 2012; 37(5):387-95.

22. Yammine $K$ and Harvey A. Antegrade intramedullary nailing for fifth metacarpal neck fractures: a systematic review and meta-analysis. European Journal of Orthopaedic Surgery \& Traumatology 2014; 24(3): 273-278.

23. Schädel-Höpfner $M$, Wild $M$, Windolf $J$, Linhart W. Antegrade intramedullary splinting or percutaneous retrograde crossed pinning for displaced neck fractures of the fifth metacarpal?. Archives of orthopaedic and trauma surgery 2007; 127(6):435-40.

24. Moon SJ, Yang JW, Roh SY, Lee DC, Kim JS. Comparison between intramedullary nailing and percutaneous $\mathrm{K}$-wire fixation for fractures in the distal third of the metacarpal bone. Archives of plastic surgery $2014 ; 41(6): 768$.

25. Fujitani R, Omokawa S, Shigematsu K, Tanaka Y. Comparison of the intramedullary nail and low-profile plate for unstable metacarpal neck fractures. Journal of Orthopaedic Science 2012; 17(4):450-6.

26. Winter M, Balaguer T, Bessiere C, Carles M, Lebreton E. Surgical treatment of the boxer's fracture: transverse pinning versus intramedullary pinning. Journal of Hand Surgery (European Volume) 2007; 32(6):709-13.

27. Wong TF and Yeung S. Comparison between percutaneous transverse fixation and intramedullary $\mathrm{K}$-wires in treating closed fractures of the metacarpal neck of the little finger. Journal of Hand Surgery 2006; 31(1): 61-65. 


$$
\text { الملخص العربى }
$$

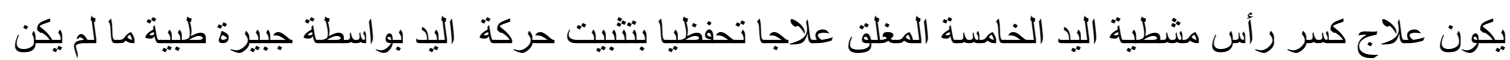

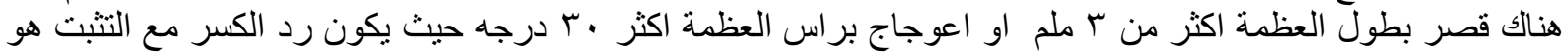

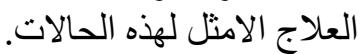

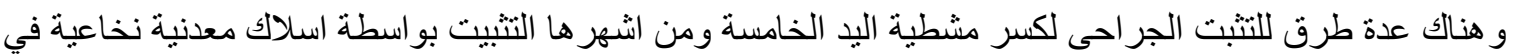

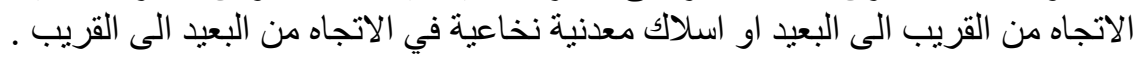

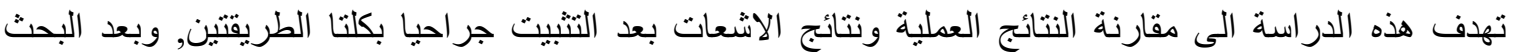

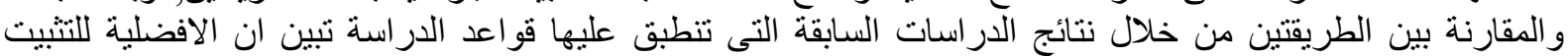

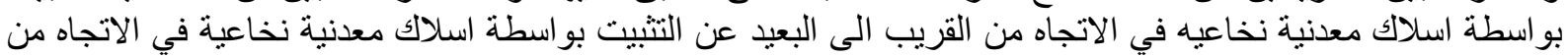
البعيد الى القريب فى عدة نقاط ومنها معدل حركة المفصل من التص والالتئام و التشوهات. 